\title{
DAMPAK INFORMASI AKUNTANSI DAN NON AKUNTANSI TERHADAP INITIAL RETURN SAHAM PADA PERUSAHAAN YANG MELAKUKAN INITIAL PUBLIC OFFERING DI BURSA EFEK INDONESIA
}

\begin{abstract}
This study aims to analyze the influence of accounting and non-accounting information of the Initial Return company shares Initial Public Offering (IPO). This study uses secondary data by taking a sample of companies that do an IPO on the Stock Exchange 2009-2012. Variables that are used in this study include the size of the company, earnings per share, price earnings ratio, financial leverage, return on assets, value stock offering, firm age, underwriter reputation, the reputation of the auditor, and the ownership of existing shareholders. The data collection method using purposive sampling and analysis of data with multiple linear regression were processed using SPSS.

The results showed that the significant effect on the initial return is the size of the company, earnings per share, price earnings ratio, underwriter reputation, and the value stock offering. While financial leverage, return on assets, the proportion of ownership of existing shareholders, underwriter reputation, and firm age no significant effect on initial returns.
\end{abstract}

Keywords: initial returns, earnings per share, financial leverage, return on assets

\section{PENDAHULUAN}

\section{Latar Belakang Masalah}

Perusahaan besar yang sedang berkembang tentunya membutuhkan dana yang besar untuk perluasan rencana bisnis. Kadangkala kebutuhan dana ini tidak dapat dipenuhi hanya dengan mengandalkan dana dari pihak internal perusahaan saja, karena keterbatasan tersebut sebuah perusahaan melakukan go public dengan cara menjual sahamnya kepada publik atau yang biasa disebut dengan Initial Public Offering (IPO). Dengan demikian, perusahaan akan berubah statusnya dari perusahaan tertutup menjadi perusahaan terbuka, yang memungkinkan investor dengan mudah mendapatkan informasi serta fakta-fakta material terkait dengan penawaran umum emiten baik berupa informasi akuntansi maupun non akuntansi. Salah satu bentuk informasi akuntansi adalah laporan keuangan, diantaranya Ukuran Perusahaan, Earning Per Share (EPS), Price Earning Ratio (PER), Financial Leverage, dan Return On Asset (ROA).

Pada saat perusahaan melakukan IPO, harga saham yang dijual pada pasar perdana ditentukan berdasarkan kesepakatan antara emiten dan penjamin emisi (underwriter), sedangkan harga yang terjadi di pasar sekunder setelah perusahaan melakukan IPO ditentukan oleh mekanisme pasar yang telah ada melalui kekuatan permintaan dan penawaran saham tersebut di pasar modal (Kurniawan, 2006 dalam Widiyanti dan Kusuma 2013). Indah (2006) dalam Widiyanti dan Kusuma (2013) menyatakan bahwa apabila harga saham pada 
saat IPO signifikan lebih rendah dibandingkan dengan harga yang terjadi di pasar sekunder dihari pertama, maka terjadi underpricing. Dan apabila terjadi overpricing, maka investorlah yang akan merugi, karena para investor tidak akan menerima Initial Return. Initial Return diperoleh dari persentase perbandingan selisih antara harga penawaran perdana (offering price) dan harga penutupan di pasar sekunder pada hari pertama (closing price) dengan harga penawaran perdana (Widiyanti dan Kusuma, 2013).

Trisyanti (2009) dalam Widiyanti dan Kusuma (2013) mengemukakan teori Adverse Selection, bahwa perusahaan yang memiliki laporan keuangan terbatas akan menyebabkan perusahaan tersebut kurang dipercaya karena adanya ketidakpastian yang diberikan oleh perusahaan tersebut. Informasi yang diungkapkan tersebut harus dapat dipercaya jika menginginkan investor menanamkan modal di IPO. Dengan kata lain, perusahaan harus menunjukkan kinerja yang baik agar informasi yang diungkapkan sesuai dengan kondisi sebenarnya.

Menurut Daruri (2012), transparansi di pasar modal Indonesia masih lemah, dan Bapepam-LK dan Bursa Efek Indonesia belum mampu membawa transparansi emiten dan perusahaan publik. Penilaiannya ini jika di bandingkan dengan Bursa Efek di London, New York dan Hongkong.Hal itu disampaikannya dalam diskusi publik akhir tahun menyoal transparansi dan akuntabilitas perusahaan publik di Jakarta, menurutnya penilaian lemahnya transparansi emiten di Indonesia terlihat dari kasus-kasus yang terjadi di pasar modal seperti kasus Bumi dan Sumalindo. Kasus-kasus seperti Bumi Plc dan Sumalindo memperlihatkan dua hal, pertama, transparansi yang ada di pasar modal tidak transparan sehingga informasi yang di keluarkan tidak benar, dan kedua, informasi yang di keluarkan menimbulkan banyak interpretasi. Kompas.com (2014), Dalam laporan keuangan Bumi Plc tahun 2011 hal 23 disebutkan adanya penghapusan akun senilai 247 juta dollar AS milik Bumi Resources dan 75 juta dollar AS milik Berau Coal. Penghapusan ini dilakukan karena auditor Bumi Plc, Pricewaterhouse Coopers LLP tidak bisa membuktikan aset dasar (underlying asset) dari sejumlah dana tersebut. Dalam laporan keuangan Bumi Resources tahun 2009, 2011, dan semester I 2012, disebutkan dana yang jumlahnya persis sama seperti yang dipermasalahkan Bumi Plc, yakni 247 juta dollar AS.Dalam laporan keuangannya, Bumi Resources tercatat menjual 20 persen saham anak usahanya yang bernama Gallo Oil Ltd kepada Florenceville Financial Ltd (Florenceville) 28 Desember 2009 silam. Gallo Oil adalah pemilik dua konsesi ladang minyak dan gas di Yaman.Nilai penjualan sebesar 290 juta dollar AS.Bumi mengklaim nilai investasi mereka atas 20 persen saham Gallo Oil adalah 247 juta dollar AS.Bumi pun mencatatkan selisih keuntungan transaksi itu sebagai laba penjualan investasi.Namun, transaksi tersebut batal pada 21 April 2011 karena Florenceville belum juga berhasil memperoleh pendanaan untuk akuisisi tersebut. Bumi Resources pun kembali menjadi pemilik 99,99 persen Gallo Oil dan laba penjualan investasi pun terpaksa mereka hapus. Adapun perihal Berau Coal, dalam laporan keuangan tahun 2011 disebutkan, dana 75 juta dollar AS itu mereka gunakan pada 26 Januari 2010 untuk membeli premiumconvertible unsecured loan notes(surat utang) dari Chateau. Berau Coal tidak mendapat bunga atas pembelian surat utang itu. Belakangan surat utang itu dikonversi menjadi kepemilikan saham di Chateau Asset Management SPC, sebuah perusahaan di kepulauan Cayman untuk dan atas nama ASEAN Mining Development Segregated Portfolio. ASEAN Mining Development Segregated 
Portfolio, seperti dalam penjelasan laporan keuangan Berau Coal 2011, adalah sebuah dana investasi dengan target akuisisi pertambangan batubara dan aset yang berkaitan dengan batubara. Termasuk juga, teknologi ramah lingkungan dengan aplikasi komersial pada pertambangan di ASEAN.Pada 30 September 2011, Berau menetapkan bahwa nilai wajar dari transaksinya itu menurun menjadi 55 juta dollar AS.Selisih kerugian itu kemudian mereka catatkan sebagai rugi penurunan nilai.

Dari ungkapan tersebut dapat kita ketahui bahwa sangat penting pula informasi non akuntansi dari perusahaan yang ingin melakukan go public. Informasi non akuntasi diantaranya, Umur Perusahaan, Reputasi Underwriter, Reputasi Auditor, Kepemilikan Pemegang Saham Lama.

Walaupun sudah banyak penelitian tentang pengaruh informasi akuntansi dan non akuntansi bagi perusahaan yang melakukan IPO, namun penelitian dalam dalam bidang ini masih dianggap sebagai suatu permasalahan yang menarik untuk diteliti kembali karena adanya ketidak konsistenan hasil penelitianpenelitian sebelumnya. Dari uraian tersebut maka penelitian ini menggunakan variabel keuangan Ukuran Perusahaan, Earning Per Share (EPS), Price Earning Ratio (PER), Financial Leverage, dan Return On Asset(ROA) dan variabel non keuangan Umur Perusahaan, Reputasi Underwriter, Reputasi Auditor, dan Kepemilikan Pemegang Saham Lama.

Penelitian Triani dan Nikmah (2006) dengan sampel perusahaan yang melakukan IPO di BEJ tahun 1994-2000 dan bukan termasuk perusahaan dari kelompok perbankan dan lembaga keuangan sejenis berkesimpulan bahwa yang berpengaruh signifikan terhadap Initial Return adalah variabel ukuran perusahaan, umur perusahaan, nilai penawaran saham, devisiasi standart return, jenis perusahaan, serta kondisi ekonomi. Sedangkan reputasi auditor dan reputasi underwriter tidak berpengaruh signifikan terhadap Initial Return. Sedangkan Widiyanti dan Kusuma (2013) dengan data pada BEl tahun 2008-2011 memberikan kesimpulan bahwa variabel yang berpengaruh signifikan secara parsial terhadap initial return saham adalah ukuran perusahaan, Earning Per Share (EPS), tingkat Leverage, Return On Asset (ROA), dan prosentase pemegang saham lama. Sedangkan Price Earnings Ratio (PER), Reputasi Auditor, Reputasi Underwriter dan umur perusahaan tidak mempunyai pengaruh signifikan terhadap initial return saham. Sementara Gabriela (2013) dengan mengambil sampel perusahaan yang melakukan IPO pada BEI periode 1992 sampai dengan 2012 mengungkapkan bahwa variabel yang berpengaruh terhadap initial return adalah variabel ukuran perusahaan dan reputasi auditor. Sedangkan umur perusahaan, nilai penawaran saham dan reputasi underwriter tidak berpengaruh secara parsial terhadap initial return.

Penelitian ini mengembangkan hasil penelitian Widiyanti dan Kusuma (2013) dengan ditambahi variabel nilai penawaran saham yang merupakan penelitian dengan hasil yang belum konsisten (Triani dan Nikmah 2006 dan Gabriela 2013).

\section{TELAAH PUSTAKA}

\section{Hubungan Logis Antar Variabel dan Perumusan Hipotesis}

Widiyanti dan Kusuma (2013), berpendapat bahwa perusahaan besar tentunya memiliki asset dan 
pendapatan besar serta siklus perputaran uang yang tinggi.Semakin besar perusahaan, semakin dikenal perusahaan oleh calon investor dan memudahkan calon investor memperoleh informasi mengenai perusahaan. Informasi yang tersedia akan menjadi bahan analisis investor dalam menentukan keputusan investasi sekaligus menjadi kontrol untuk mengetahui kondisi suatu perusahaan sehingga dapat meningkatkan penilaian perusahaan, juga pengurang tingkat ketidakpastian dan minimalisir tingkat resiko.

H1 : Ukuran Perusahaan berpengaruh signifikan terhadap Initial Return.

Earning Per Share menggambarkan laba yang diperoleh perusahaan per lembar sahamnya. Earning Per Share berhubungan dengan risiko dan performance perusahaan. Informasi yang dihasilkan dari Earning Per Share berguna bagi investor untuk mengetahui perkembangan perusahaan. Apabila Earning Per Share perusahaan tinggi, akan semakin banyak investor yang membeli saham tersebut sehingga menyebabkan harga saham tinggi. (Widiyanti dan Kusuma, 2013).

\section{H2 : Earning Per Share (EPS) tidak berpengaruh signifikan terhadap Initial Return.}

Price Earning Ratio merupakan fungsi dari resiko dan pertumbuhan earnings di masa yang akan datang. Semakin kecil nilai price earning ratio maka semakin murah saham dibeli dan semakin baik pula kinerja perusahaan. Semakin baik kinerja per lembar saham akan mempengaruhi banyak investor untuk membeli saham tersebut. Sehingga price earning ratio dapat digunakan untuk melakukan penilaian atas perusahaan agar mendorong keputusan investor dalam membeli saham perusahaan di pasar perdana (Widiyanti dan Kusuma, 2013).

\section{H3 : Besarnya Price Earning Ratio (PER) berpengaruh signifikan terhadap Initial Return.}

Semakin besar Financial Leverage mencerminkan resiko perusahaan yang relative tinggi. IPO saham dari emiten dengan rasio Financial Leverage yang tinggi akan menciptakan sentiment negatif bagi investor dalam membeli saham perusahaan tersebut (Ratnasari dan Hudiwinarsih, 2013). Sehingga biasanya pada keadaan ini dalam melakukan IPO, emiten akan menawarkan saham dengan harga relative rendah dibawah harga sewajarnya sehingga Initial Return meningkat. Karena jika harga saham relatif tinggi maka akan terjadi keadaan overpricing yang menyebabkan investor tidak mendapatkan return awal.

\section{H4 : Financial Leverage tidak berpengaruh signifikan terhadap Initial Return.}

ROA merupakan salah satu rasio profitabilitas, yaitu estimasi rasio yang menunjukan seberapa efektifnya perusahaan beroperasi sehingga menghasilkan keuntungan atau laba bagi perusahaan.ROA menjadi salah satu pertimbangan para investor di dalam melakukan investasi. Nilai ROA yang semakin tinggi akan menunjukkan bahwa perusahaan mampu menghasilkan laba di masa yang akan datang dan laba merupakan informasi penting bagi investor sebagai pertimbangan dalam menanamkan modalnya. Profitabilitas yang tinggi dari suatu perusahaan akan mengurangi ketidakpastian bagi investor sehingga akan menaikan tingkat 
underpricing (Handayani, 2008 dalan Widiyanti dan Kusuma, 2013).

\section{H5 : Return On Asset (ROA) berpengaruh signifikan terhadap Initial Return.}

Sulistyo (2005) dalam Widiyanti dan Kusuma (2013) menyatakan bahwa proporsi kepemilikan saham yang ditahan oleh pemilik saham lama menggambarkan tingkat kepercayaan manajemen dan pemegang saham lama akan keberhasilan IPO. Pemegang saham lama dan manajemen tidak akan melepaskan proporsi kepemilikan dalam perusahaan bila mereka tidak yakin akan keberhasilan IPO sehingga proporsi kepemilikan saham yang ditahan oleh pemegang saham lama dapat dipertimbangkan sebagai faktor yang yang turut membangun keyakinan investor akan keberhasilan IPO perusahaan.

\section{H6 : Proporsi Kepemilikan Pemegang Saham Lama berpengaruh signifikan terhadap Initial Return.}

Emiten yang menggunakan auditor berkualitas akan diinterpretasikan oleh investor bahwa emitem mempunyai informasi yang tidak salah mengenai prospeknya dan mengurangi ketidakpastian di masa yang akan datang (Gabriela, 2013). Arini (2011) dalam Widiyanti dan Kusuma (2013) juga menyatakan bahwa kebenaran terhadap informasi laporan keuangan inilah yang menjadi referensi investor dalam menentukan keputusan investasi, investor menganggap laporan keuangan tersebut dapat digunakan sebagai alat analisis dalam menilai kemampuan perusahaan sebenarnya.

\section{H7 : Reputasi Auditor berpengaruh signifikan terhadap Initial Return.}

Sulistyo (2005) dalam Widiyanti dan Kusuma (2013) menyatakan bahwa underwriter yang bereputasi tinggi lebih berpengalaman dan professional dalam menangani IPO perusahaan. Mereka juga mempunyai beban moral yang lebih besar untuk mempertahankan reputasi baiknya sehingga pemilihan underwriter yang berkualitas akan memberikan keyakinan lebih bagi investor akan keberhasilan IPO perusahaan. Perusahaan tentunya tidak menginginkan jika dalam pelaksanaan penawaran umum timbul keraguan, apaah efek yang dilepas ke para investor akan terjual habis atau tidak, bila setelah dilepas efek tersebut tidak terjual habis, maka akan mengakibatkan kerugian, sebab biaya yang dikeluarkan tidak dapat ditarik kembali, juga akan menjatuhkan reputasi perusahaan, untuk itu penjamin emisi efek sangat diperlukan. Reputasi penjamin emisi yang baik dapat menurunkan tingkat resiko perusahaan sehingga dapat memberikan Initial Return bagi investor.

\section{H8 : Reputasi Underwriter berpengaruh signifikan terhadap Initial Return.}

Umur perusahaan merupakan salah satu hal yang dipertimbangkan investor dalam menanamkan modalnya pada suatu perusahaan. Widiyanti dan Kusuma (2013) menjelaskan bahwa variabel ini diukur dengan lamanya perusahaan beroperasi yaitu sejak perusahaan itu didirikan (established date) sampai dengan saat perusahaan melakukan IPO (listing date). Dalam kondisi normal, perusahaan yang telah lama berdiri akan mempunyai publikasi perusahaan lebih banyak dibandingkan dengan perusahaan yang masih baru. Jadi 
perusahaan yang telah lama berdiri mempunyai tingkat underpriced tinggi daripada perusahaan yang masih baru karena mengurangi asimetri informasi dan memperkecil ketidakpastian pasar. Dengan demikian diyakini perusahaan yang sudah lama berdiri bisa dikatakan lebih berpengalaman dalam menghasilkan return bagi perusahaan yang pada akhirnya berdampak pada meningkatnya return yang diterima investor.

\section{H9 : Umur Perusahaan berpengaruh signifikan terhadap Initial Return.}

(Junaeni dan Agustian, 2013) menjelaskan pada saat perusahaan menawarkan saham baru, maka terdapat aliran kas masuk dari proceeds (penerimaan dari pengeluaran saham). Proceeds menunjukan besarnya ukuran penawaran saham pada saat IPO.Penetapan pada harga penawaran (offering price) adalah berapa harga saham dalam suatu perusahaan yang untuk pertama kalinya ditawarkan kepada publik.Hal ini tidak mudah dilakukan. Kepatan harga penawaran dalam pasar perdana akan memiliki konsekuensi langsung terhadap tingkat kesejahteraan pemilik lama (issuers). Pihak issuers tentu mengharapkan harga jual yang tinggi, karena dengan harga jual yang tinggi penerimaan dari hasil penawaran (proceeds) akan tinggi pula, yang berarti tingkat kesejahteraannya (wealth) akan semakin baik. Ditambahkan menurut Gumanti (2000) dalam Junaeni dan Agustian (2013) keterbatasan informasi tentang perusahaan yang akango public menyebabkan tidak ada dasar yang relevan tentang bagaimana harga penawaran ditetapkan. Oleh karena itu, diduga bahwa proceedsberhubungan positif dengan harga pasar saham karena semakin tinggi proceeds, semakin rendah ketidakpastian yang berarti semakin tinggi harga saham. Dengan demikian dapat disusun hipotesis sebagai berikut :

\section{H10 : Nilai Penawaran Saham berpengaruh signifikan terhadap Initial Return.}

\section{METODE PENELITIAN}

Variabel dependen dalam penelitian ini adalah Initial Return, sedangkan variabel independen yang digunakan adalah ukuran perusahaan, earning per share, price earning ratio, financial leverage, return on asset, nilai penawaran saham, proporsi kepemilikan pemegang saham lama, reputasi auditor, reputasi underwriter dan umur perusahaan. Metode pemilihan sampel yang digunakan adalah metode purposive sampling, didapatkan sebanyak 58perusahaan yang melakukan IPO dan terdaftar di Bursa Efek Indonesia (BEI) pada periode tahun 2009-2012. Metode analisis menggunakan regresi liner berganda dengan menggunakan spss.

\section{HASIL DAN PEMBAHASAN}

\section{Statistik Deskriptif}

Statistik Deskriptif digunakan untuk melihat gambaran data. Dalampenelitian ini

data yang akan kita ketahui gambarannya adalah data Informasi Akuntansi (Ukuran Perusahaan, Earning Per Share, Price Earning Ratio, Financial Leverage,Return On Asset, Nilai Penawaran Saham) dan Informasi Non Akuntansi (Kepemilikan Pemegang Saham Lama,Reputasi Auditor, Reputasi Underwriter, Umur Perusahaan) berpengaruh terhadap Initial Return. Hasil statistik deskriptif disajikan pada Tabel 1 (lampiran). 
Berdasarkan hasil perhitungan deskriptif tersebut nampak bahwa dari 58 data pengamatan, ukuran perusahaan selama periode pengamatan mempunyai nilai rata-rata sebesar 4444209 dalam jutaan rupiah dengan standar deviasi sebesar 8425440,987. Nilai minimum sebesar 22185 dan nilai maximum sebesar 44992171.EPS selama periode pengamatan mempunyai nilai rata-rata sebesar 90,5949 dengan standar deviasi sebesar 163,53250. Nilai minimum sebesar -35 dan nilai maximum sebesar 843.PER selama periode pengamatan mempunyai nilai rata-rata sebesar 63,1672 dengan standar deviasi sebesar 145,14397. Nilai minimum sebesar -13,6 dan nilai maximum sebesar 961,54.Leverage selama periode pengamatan mempunyai nilai rata-rata sebesar 0,6053 dengan standar deviasi sebesar 0,53100. Nilai minimum sebesar 0,03 dan nilai maximum sebesar 4,18.ROA selama periode pengamatan mempunyai nilai rata-rata sebesar 6,8640 dengan standar deviasi sebesar 8,37857. Nilai minimum sebesar $-5,20$ dan nilai maximum sebesar 40,26. Proporsi kepemilikan saham lama selama periode pengamatan mempunyai nilai rata-rata sebesar 69,3445\% dengan standar deviasi sebesar 18,21180. Nilai minimum sebesar 22,48 dan nilai maximum sebesar 97 . Reputasi auditor selama periode pengamatan mempunyai nilai rata-rata sebesar 0,3793 dengan standar deviasi sebesar 0,48945. Nilai minimum sebesar 0 dan nilai maximum sebesar 1 . Nilai rata-rata dibawah 0,5 sehingga banyak sample yang berkode 0 dan tidak menggunakan jasa auditor yang berafiliasi. Reputasi underwriter selama periode pengamatan mempunyai nilai rata-rata sebesar 0,5345 dengan standar deviasi sebesar 0,50317 . Nilai minimum sebesar 0 dan nilai maximum sebesar 1 . Nilai rata-rata diatas 0,5 sehingga banyak sample yang berkode 1 atau menggunakan jasa 20 top broker. Umur perusahaan selama periode pengamatan nilai rata-rata sebesar 17,7069 dengan standar deviasi sebesar 15,27297. Nilai minimum sebesar 1 dan nilai maximum sebesar 75.NIlai Penawaran Saham selama periode pengamatan mempunyai nilai rata-rata sebesar 3836438859583,4 dengan standar deviasi sebesar5742817630830,7. Nilai minimum sebesar 82000000000 dan nilai maximum sebesar 3323643780000000. Initial Return selama periode pengamatan mempunyai nilai ratarata sebesar 22,7638 dengan standar deviasi sebesar 20,57253. Nilai minimum sebesar 1,06 dan nilai maximum sebesar 72,73 .

\section{ANALISA DATA}

\section{Uji Asumsi Klasik}

\section{Uji Normalitas}

Uji normalitas bertujuan untuk menguji apakah dalam model regresi, variabel residual memiliki distribusi normal.Untuk menguji apakah distribusi data normal atau tidak.

\section{Uji Multikolinearitas}

Uji multikolinearitas bertujuan untuk menguji apakah dalam model regresi ditemukan adanya korelasi antar variabel independen. Untuk mendeteksi ada atau tidaknya multikolinearitas dengan menganalisis matriks korelasi variabel-variabel bebas.

Dari hasil pada Tabel 3 (lampiran), dapat dilihat bahwa dalam model regresi tidak terjadi multikolinearitas 
karena nilai VIF $<=10$ dan nilai tolerance $>=0,10$.

\section{Uji Heteroskedastisitas}

Heteroskedastisitas menguji terjadinya perbedaan variance residual suatu periode pengamatan ke periode pengamatan yang lain. Cara memprediksi ada tidaknya heteroskedastisitas pada suatu model menggunakan Uji Glejser.Glejser mengusulkan untuk meregres nilai absolute residual terhadap variabel independen (Gujarati, 2003) dalam Ghozali (2011).

Dari hasil perhitungan di Tabel 4 (lampiran), menunjukkan tidak ada gangguan heteroskedastisitas yang terjadi dalam proses estimasi parameter model penduga, dimana tidak ada nilai t-hitung yang signifikan atau nilai signifikan (sig) lebih dari 0,05 (p>0,05). Jadi secara keseluruhan dapat disimpulkan bahwa tidak ada masalah heteroskedastisitas.

\section{Uji Autokorelasi}

Menguji autokorelasi dalam suatu model bertujuan untuk mengetahui ada tidaknya korelasi antara variabel pengganggu pada periode tertentu dengan variabel sebelumnya.

Dari hasil SPSS diatas terlihat bahwa nilai Durbin Watson sebesar $d=1,700$, hasil nilai Durbin Watson ini masuk dalam Angka D-W di antara -2 dan +2 berarti tidak ada autokorelasi.

\section{Uji Hipotesis Secara Parsial (Uji t)}

Uji ini digunakan untuk menentukkan analisis pengaruh Informasi Akuntansi (Ukuran Perusahaan, Earning PerShare, Price Earning Ratio, Financial Leverage, dan Return On Asset, Nilai penawaran saham) dan Informasi Non Akuntansi (Kepemilikan Pemegang Saham Lama,Reputasi Auditor, Reputasi Underwriter, Umur Perusahaan) berpengaruh terhadap Initial Return pada perusahaan yang melakukan IPO di BEI Tahun 2009-2012. Secara parsial, yang dapat dilihat dari besarnya t hitung terhadap t tabel dengan uji 1 sisi. Dalam penelitian ini diketahui bahwa $n=58$ pada tingkat signifikan $5 \%$. Pada tingkat kesalahan $(\alpha=0,05)$ dengan menggunakan uji 1 sisi diperoleh nilai t tabel $(57 ; 0,05)$ sebesar 1,672 Sedangkan t hitung dari variabel independent terlihat pada Tabel 6 (lampiran).

Hasil Tabel 6 dijelaskan sebagai berikut :

1. Variabel ukuran perusahaan diduga berpengaruh terhadap Initial Returnpada perusahaan yang melakukan IPO di Tahun 2009-2012. Nilai sig 0,023 dibawah 0,05. Hasil perhitungan pada regresi berganda diperoleh

nilai $\mathrm{t}_{\text {hitung }}$ sebesar 2,348. Dengan demikian $\mathrm{t}_{\text {hitung }}$ berada pada daerah $\mathrm{H}_{0}$ ditolak dan $\mathrm{H}_{\mathrm{a}}$ diterima maka angka tersebut menunjukkan nilai yang signifikan yang artinya terdapat pengaruh antara ukuran perusahaan terhadap Initial Return pada perusahaan yang melakukan IPO di BEI Tahun 2009-2012. Pernyataan H1 diterima.

2. Variabel EPS diduga tidak berpengaruh terhadap Initial Return pada perusahaan yang melakukan IPO di BEI Tahun 2009-2012. Nilai sig 0,001 dibawah 0,05. Hasil perhitungan pada regresi berganda diperoleh 
nilai $t_{\text {hitung }}$ sebesar 3,399. Dengan demikian $t_{\text {hitung }}$ berada pada daerah $\mathrm{H}_{0}$ ditolak dan $\mathrm{H}_{\mathrm{a}}$ diterima maka angka tersebut menunjukkan nilai yang signifikan yang artinya terdapat pengaruh antara EPS terhadap Initial Return pada perusahaan yang melakukan IPO di BEI Tahun 2009-2012. Pernyataan H2 ditolak.

3. Variabel PER diduga berpengaruh terhadap Initial Return pada perusahaan yang melakukan IPO di BEI Tahun 2009-2012. Nilai sig 0,008 dibawah 0,05. Hasil perhitungan pada regresi berganda diperoleh nilai $\mathrm{t}_{\text {hitung }}$ sebesar 2,759. Dengan demikian $\mathrm{t}_{\text {hitung }}$ berada pada daerah $\mathrm{H}_{0}$ ditolak dan $\mathrm{H}_{\mathrm{a}}$ diterima maka angka tersebut menunjukkan nilai yang signifikan yang artinya terdapat pengaruh antara PER terhadap Initial Return pada perusahaan yang melakukan IPO di BEI Tahun 2009-2012. Pernyataan H3 diterima.

4. Variabel Leverage diduga tidak berpengaruh terhadap Initial Return pada perusahaan yang melakukan IPO di BEI Tahun 2009-2012. Nilai sig 0,484 diatas 0,05. Hasil perhitungan pada regresi berganda diperoleh nilai $\mathrm{t}_{\text {hitung }}$ sebesar $-0,706$. Dengan demikian $\mathrm{t}_{\text {hitung }}$ berada pada daerah $\mathrm{H}_{0}$ diterima dan $\mathrm{H}_{\mathrm{a}}$ ditolak maka angka tersebut menunjukkan nilai yang tidak signifikan yang artinya tidak terdapat pengaruh antara Leverage terhadap Initial Return pada perusahaan yang melakukan IPO di BEI Tahun 2009-2012. Pernyataan H4 diterima.

5. Variabel ROA diduga berpengaruh terhadap Initial Return pada perusahaan yang melakukan IPO di Tahun 2009-2012. Nilai sig 0,469 diatas 0,05. Hasil perhitungan pada regresi berganda diperoleh nilai $t_{\text {hitung }}$ sebesar 0,730 . Dengan demikian $\mathrm{t}_{\text {hitung }}$ berada pada daerah $\mathrm{H}_{0}$ diterima dan $\mathrm{H}_{\mathrm{a}}$ ditolak maka angka tersebut menunjukkan nilai yang tidak signifikan yang artinya tidak terdapat pengaruh antara ROA terhadap Initial Return pada perusahaan yang melakukan IPO di BEI Tahun 2009-2012. Pernyataan H5 ditolak.

6. Variabel proporsi kepemilikan saham lama saham lamadiduga berpengaruh terhadap Initial Return pada perusahaan yang melakukan IPO di BEI Tahun 2009-2012. Nilai sig 0,941diatas 0,05. Hasil perhitungan pada regresi berganda diperoleh nilai $\mathrm{t}_{\text {hitung }}$ sebesar 0,075 . Dengan demikian $\mathrm{t}_{\text {hitung }}$ berada pada daerah $\mathrm{H}_{0}$ diditerima dan $\mathrm{H}_{\mathrm{a}}$ ditolak maka angka tersebut menunjukkan nilai yang tidak signifikan yang artinya tidak terdapat pengaruh antara proporsi kepemilikan saham lama saham lama terhadap Initial Return pada perusahaan yang melakukan IPO di BEI Tahun 2009-2012. Pernyataan H6 ditolak.

7. Variabel Reputasi Auditordiduga berpengaruh terhadap Initial Return pada perusahaan yang melakukan IPO di BEI Tahun 2009-2012. Nilai sig 0,484diatas 0,05. Hasil perhitungan pada regresi berganda diperoleh nilai $t_{\text {hitung }}$ sebesar 0,706 . Dengan demikian $t_{\text {hitung }}$ berada pada daerah $\mathrm{H}_{0}$ diterima dan $\mathrm{H}_{\mathrm{a}}$ ditolak maka angka tersebut menunjukkan nilai yang tidak signifikan yang artinya tidak terdapat pengaruh antara reputasi auditor terhadap Initial Return pada perusahaan yang melakukan IPO di BEI Tahun 2009-2012. Pernyataan $\mathbf{H 7}$ ditolak.

8. Variabel Reputasi Underwriter diduga berpengaruh terhadap Initial Return pada perusahaan yang melakukan IPO di BEI Tahun 2009-2012. Nilai sig 0,004 dibawah 0,05. Hasil perhitungan pada regresi berganda diperoleh nilai $t_{\text {hitung }}$ sebesar 3,039. Dengan demikian $t_{\text {hitung }}$ berada pada daerah $\mathrm{H}_{0}$ ditolak dan $\mathrm{H}_{\mathrm{a}}$ diterima maka angka tersebut menunjukkan nilai yang signifikan yang artinya terdapat pengaruh antara reputasi underwriter terhadap Initial Return pada perusahaan yang melakukan IPO di BEI Tahun 
2009-2012. Pernyataan H8 diterima.

9. Variabel umur perusahaan diduga berpengaruh terhadap Initial Return pada perusahaan yang melakukan IPO di BEI Tahun 2009-2012. Nilai sig 0,822diatas 0,05. Hasil perhitungan pada regresi berganda diperoleh nilai $\mathrm{t}_{\text {hitung }}$ sebesar 0,226 . Dengan demikian $\mathrm{t}_{\text {hitung }}$ berada pada daerah $\mathrm{H}_{0}$ diterima dan $\mathrm{H}_{\mathrm{a}}$ ditolak maka angka tersebut menunjukkan nilai yang tidak signifikan yang artinya tidak terdapat pengaruh antara umur perusahaan terhadap Initial Return pada perusahaan yang melakukan IPO di BEI Tahun 2009-2012. Pernyataan $\mathbf{H} \mathbf{9}$ ditolak.

10. Variabel Nilai Penawaran Saham berpengaruh terhadap Initial Return pada perusahaan yang melakukan IPO di BEI Tahun 2009-2012. Nilai sig 0,003 dibawah 0,05. Hasil perhitungan pada regresi berganda diperoleh nilai $t_{\text {hitung }}$ sebesar 3,102. Dengan demikian $\mathrm{t}_{\text {hitung }}$ berada pada daerah $\mathrm{H}_{0}$ ditolak dan $\mathrm{H}_{\mathrm{a}}$ diterima maka angka tersebut menunjukkan nilai yang signifikan yang artinya terdapat pengaruh antara jenis industri terhadap Initial Return pada perusahaan yang melakukan IPO di BEI Tahun 2009-2012. Pernyataan H10 diterima.

\section{Uji Simultan (Uji F)}

Pengujian ini untuk menguji pengaruh Informasi Akuntansi (Ukuran Perusahaan, Earning Per Share, Price Earning Ratio, Financial Leverage, dan Return On Asset, Nilai Penawaran Saham) dan Informasi Non Akuntansi (Kepemilikan Pemegang Saham Lama,Reputasi Auditor, Reputasi Underwriter, Umur Perusahaan) berpengaruh terhadap Initial Return pada perusahaan yang melakukan IPO di BEI Tahun 2009-2012 secara simultan.

Hasil dari Tabel 7 (lampiran) tentang Uji Simultan F :

Jika $\mathrm{F}$ hitung $>\mathrm{F}$ tabel, maka Ho ditolak dan Ha diterima.

Jika F hitung $<$ F tabel, maka Ho diterima dan Ha ditolak. Atau

Jika $\mathrm{p}<0,05$, maka Ho ditolak dan Ha diterima.

Jika $\mathrm{p}>0,05$, maka Ho diterima dan Ha ditolak.

Dengan tingkat signifikan 5\% dan derajat kebebasan df1 = 10 dan df2 = 47 maka tabel didapat $F(10 ; 47)$ $=2,039$. Dalam perhitungan diperoleh nilai F hitung lebih besar dari F tabel, yaitu 9,455>2,039 sehingga Ho ditolak Sedangkan jika dilihat dari nilai sig hitung adalah 0,000 yaitu $<0,05$ maka keputusannya juga menolak Ho yang berarti Hal ini menunjukkan bahwa secara simultan terdapat pengaruh Informasi Akuntansi (Ukuran Perusahaan, Earning Per Share, Price Earning Ratio, Financial Leverage,Return On Asset, Nilai Penawaran Saham,) dan Informasi Non Akuntansi (Kepemilikan Pemegang Saham Lama,Reputasi Auditor, Reputasi Underwriter, Umur Perusahaan) berpengaruh terhadap Initial Return pada perusahaan yang melakukan IPO di BEITahun 2009-2012.

\section{Koefisien Determinasi $\left(\mathbf{R}^{2}\right)$}

Koefisien Determinasi $\left(R^{2}\right)$ bertujuan untuk mengukur seberapa jauh kemampuan model dalam menerangkan variasi variabel dependen. Nilai koefisien determinasi adalah antara nol dan satu. Nilai $R^{2}$ yang 
kecil berarti kemampuan variabel-variabel independen dalam menjelaskan variasi variabel dependen sangat terbatas, nilai $R^{2}$ terlihat pada Tabel 8 (lampiran).

Hasil analisis regresi linier berganda tersebut dapat terlihat dariR square sebesar 0,668 yang menunjukkan bahwa Initial Return pada perusahaan yang melakukan IPO di BEI Tahun 2009-2012 dipengaruhi oleh sepuluh variabel yaitu Informasi Akuntansi (Ukuran Perusahaan, Earning Per Share, Price Earning Ratio, Financial Leverage,Return On Asset, Nilai Penawaran Saham) dan Informasi Non Akuntansi (Umur Perusahaan, Reputasi Underwriter, Reputasi Auditor, Kepemilikan Pemegang Saham Lama) sebesar 66,8\%, sisanya yaitu 33,2\%,Initial Return dipengaruhi variabel lain yang belum diteliti dalam penelitian ini.Sedangkan Standart Error of the Estimate (SEE) sebesar 13,05462. Semakin kecil nilai SEE akan membuat model regresi semakin tepat dalam memprediksi variabel dependen.

\section{PEMBAHASAN}

\section{Ukuran Perusahaan terhadap Initial Return}

Hipotesis 1 diterima, ukuran perusahaan berpengaruh signifikan terhadap Initial Return. Hasil SPSS menunjukan nilai t hitung $(2,348)$ lebih besar dari t tabel $(1,672)$ signifikansi $(0,023)$ lebih kecil dari 0,05 dan nilai koefisiensi ukuran perusahaan sebesar $(0,603)$. Hasil penelitian ini selaras dengan hasil penelitian sebelumnya yang dilakukan oleh Widiyanti dan Kusuma (2013) yang berpendapat bahwa perusahaan besar tentunya memiliki asset dan pendapatan besar serta siklus perputaran uang yang tinggi. Semakin besar perusahaan, semakin dikenal perusahaan oleh calon investor dan memudahkan calon investor memperoleh informasi mengenai perusahaan. Informasi yang tersedia akan menjadi bahan analisis investor dalam menentukan keputusan investasi sekaligus menjadi kontrol untuk mengetahui kondisi suatu perusahaan sehingga dapat meningkatkan penilaian perusahaan, juga pengurang tingkat ketidakpastian dan minimalisir tingkat resiko. Ditambahkan menurut Gabriela (2013), ukuran perusahaan dapat dijadikan proxy tingkat ketidakpastian saham. Perusahaan berskala besar cenderung lebih dikenal masyarakat sehingga informasi mengenai prospek perusahaan berskala besar lebih mudah diperoleh investor daripada perusahaan berskala kecil. Sedangkan Ardiyansyah (2004) dalam Gabriela (2013) mengemukakan tingkat ketidakpastian yang akan dihadapi investor mengenai masa depan perusahaan emiten dapat diperkecil apabila informasi yang diperolehnya banyak. Dengan rendahnya perusahaan yang berskala kecil maka kemungkinan return yang diterima investor akan semakin rendah karena terdapat ketidakpastian yang terjadi dimasa yang akan datang, sehingga dapat dikatakan ukuran perusahaan mempengaruhi initial return.

\section{EPS terhadap Initial Return}

Hipotesis 2 ditolak, EPS berpengaruh signifikan terhadap Initial Return. Hasil SPSS menunjukan nilai t hitung $(3,399)$ lebih besar dari t tabel $(1,672)$ signifikansi $(0,001)$ lebih kecil dari 0,05 dan nilai koefisiensi ukuran perusahaan sebesar (0,015). Hasil Penelitian ini sama dengan penelitian Widiyanti dan Kusuma (2013) dimana Earning Per Share menggambarkan laba yang diperoleh perusahaan per lembar sahamnya. Earning 
Per Share berhubungan dengan risiko dan performance perusahaan. Informasi yang dihasilkan dari Earning Per Share berguna bagi investor untuk mengetahui perkembangan perusahaan. Apabila Earning Per Share perusahaan tinggi, akan semakin banyak investor yang membeli saham tersebut sehingga menyebabkan harga saham tinggi. Sehingga hal ini akan mengakibatkan pengaruh yang negatif dan signifikan terhadap Initial Returnsaham dimana akan sedikitnya Initial Return Saham yang diperoleh investor.

\section{PER terhadap Initial Return}

Hipotesis 3 diterimaPER berpengaruh signifikan terhadap Initial Return. Hasil SPSS menunjukan nilai t hitung $(2,759)$ lebih besar dari t tabel $(1,672)$ signifikansi $(0,008)$ lebih kecil dari 0,05 dan nilai koefisiensi ukuran perusahaan sebesar (0,036). Hasil Penelitian ini selaras dengan Lutfianto (2013) dalam Widiyanti dan Kusuma (2013) yang menyatakan bahwa Price Earning Ratio berpengaruh positif dan signifikan terhadap Initial Return.Semakin kecil nilai price earning ratio, semakin murah saham dibeli maka semakin baik pula kinerja perusahaan. Dan semakin baik kinerja per lembar saham akan mempengaruhi banyak investor untuk membeli saham tersebut.

\section{Leverage terhadap Initial Return}

Hipotesis 4 diterima,Leverage tidak berpengaruh signifikan terhadap Initial Return. Hasil SPSS menunjukan nilai thitung $(-0,706)$ lebih kecil dari t tabel $(1,672)$ signifikansi $(0,484)$ lebih besar dari 0,05 dan nilai koefisiensi ukuran perusahaan sebesar $(-1,897)$.Hasil yang serupa dinyatakan oleh Junaeni dan Agustian (2013) yang menyatakan secara parsial tidak terdapat pengaruh yang signifikan dari financial leverage terhadap tingkat underpricing saham dengan arah negatif. Semakin tinggi tingkat leverage suatu perusahaan, semakin tinggi pula tingkat resiko dan ketidakpastian yang dihadapi perusahaan (Sulistyo, 2005 dalam Widiyanti dan Kusuma, 2013).

\section{ROA terhadap Initial Return}

Hipotesis 5 ditolak,ROAtidakberpengaruh signifikan terhadap

Initial Return. Hasil SPSS menunjukan nilai t hitung $(0,730)$ lebih kecil dari t tabel $(1,672)$ signifikansi $(0,469)$ lebih besar dari 0,05 dan nilai koefisiensi ukuran perusahaan sebesar $(0,015)$.ROA merupakan salah satu rasio profitabilitas, yaitu estimasi rasio yang menunjukan seberapa efektifnya perusahaan beroperasi sehingga menghasilkan keuntungan atau laba bagi perusahaan. ROA menjadi salah satu pertimbangan para investor di dalam melakukan investasi. Nilai ROA yang semakin tinggi akan menunjukkan bahwa perusahaan mampu menghasilkan laba di masa yang akan datang dan laba merupakan informasi penting bagi investor sebagai pertimbangan dalam menanamkan modalnya. Profitabilitas yang tinggi dari suatu perusahaan akan mengurangi ketidakpastian bagi investor sehingga akan menaikan tingkat underpricing (Handayani, 2008 dalan Widiyanti dan Kusuma, 2013). Hal ini memungkinkan tingginya Initial Return bagi investor dan ROA yang menunjukkan kemampuan suatu perusahaan dalam menghasilkan laba bersih menjadi hal yang diperhatikan 
investor dalam mengambil keputusan investasi. Dalam hasil penelitian ini ROA berpengaruh positif namun karena pengaruhnya kecil jadi dapat dikatakan ROA tidak signifikan terhadap initial return.

\section{Proporsi Kepemilikan Pemegang Saham Lama terhadap/nitial Return}

Hipotesis 6 ditolak,Proporsi kepemilikan pemegang saham lamatidak berpengaruh signifikan terhadap Initial Return. Hasil SPSS menunjukan nilai t hitung $(0,075)$ lebih kecil dari t tabel $(1,672)$ signifikansi $(0,941)$ lebih besar dari 0,05 dan nilai koefisiensi ukuran perusahaan sebesar (0,005).Sulistio (2005) dalam Widiyanti dan Kusuma (2013) menyatakan bahwa proporsi kepemilikan saham yang ditahan oleh pemilik saham lama menggambarkan tingkat kepercayaan manajemen dan pemegang saham lama akan keberhasilan IPO. Pemegang saham lama dan manajemen tidak akan melepaskan proporsi kepemilikan dalam perusahaan bila mereka tidak yakin akan keberhasilan IPO sehingga proporsi kepemilikan saham yang ditahan oleh pemegang saham lama dapat dipertimbangkan sebagai faktor yang yang turut membangun keyakinan investor akan keberhasilan IPO perusahaan. Dari hasil penelitian ini proporsi kepemilikan saham lama memang berpengaruh positif namun karena pengaruhnya kecil maka dapat dikatakan proporsi kepemilikan pemegang saham lama tidak signifikan terhadap initial return.

\section{Reputasi Audito terhadap/nitial Return}

Hipotesis 7 ditolak,Reputasi Auditortidak berpengaruh signifikan terhadap Initial Return. Hasil SPSS menunjukan nilai t hitung $(0,706)$ lebih kecil dari t tabel $(1,672)$ signifikansi $(0,484)$ lebih besar dari 0,05 dan nilai koefisiensi ukuran perusahaan sebesar $(2,872)$. Hasil penelitian ini selaras dengan hasil penelitian Arini (2007) dalam Widiyanti dan Kusuma (2013) yang menyatakan bahwa kebenaran terhadap informasi laporan keuangan inilah yang menjadi referensi investor dalam menentukan keputusan investasi, investor mengangap laporan keuangan tersebut dapat digunakan sebagai alat analisis dalam menilai kemampuan perusahaan sebenarnya. Namun terkadang tingkat kepercayaan masyarakat terhadap hasil laporan auditor, jasa auditor yang digunakan pada saat perusahaan melakukan IPO belum tentu membuktikan bahwa laporan keuangan perusahaan menunjukkan kreibilitas yang baik dan dapat dipercaya, walaupun emiten telah menggunakan auditor yang telah berafiliasi dengan KAP asing.

\section{Reputasi Underwriter terhadap Initial Return}

Hipotesis 8 diterima,ReputasiUnderwriter berpengaruh signifikan terhadap Initial Return. Hasil SPSS menunjukan nilai t hitung $(3,039)$ lebih besar dari t tabel $(1,672)$ signifikansi $(0,004)$ lebih kecil dari 0,05 dan nilai koefisiensi ukuran perusahaan sebesar $(11,469)$. Hasil penelitian ini konsisten dengan hasil penelitian yang dilakukan Juaeni dan Agustian (2013) yang menyatakan secara parsial terdapat pengaruh yang signifikan reputasi underwriter terhadap tingkat underpricing saham dengan arah negatif.Sehingga semakin tinggi reputasi underwriter maka semakin rendah tingkat underpricing.Arah negative menunjukkan bahwa reputasi underwriter berlawanan terhadap tingkat underpricing saham.Namun berbanding terbalik dengan penelitian 
Sulistyo (2005) dalam Widiyanti dan Kusuma (2013) yang menyatakan reputasi underwriter berpengaruh positif dan tidak signifikan terhadap initial return.

\section{Umur Perusahaan terhadap Initial Return}

Hipotesis 9 ditolak,Umur Perusahaantidak berpengaruh signifikan terhadap Initial Return. Hasil SPSS menunjukan nilai t hitung $(0,226)$ lebih kecil dari t tabel $(1,672)$ signifikansi $(0,822)$ lebih besar dari 0,05 dan nilai koefisiensi ukuran perusahaan sebesar $(0,115)$. Hasil penelitian ini konsisten dengan hasil penelitian Daljono (2000) dalam Gabriela (2013) yang menyatakan bahwa umur perusahaan menunjukan seberapa lama perusahaan mampu bertahan, semakin lama umur perusahaan maka semakin banyak informasi yang telah diperoleh masyarakat tentang perusahaan tersebut. Ini akan bermanfaat untuk investor dalam mengurangi tingkat ketidakpastian perusahaan. Dengan demikian calon investor tidak perlu mengeluarkan biaya yang lebih banyak untuk memperoleh informasi tentang perusahaan yang melakukan IPO tersebut. Jadi, perusahaan yang telah lama berdiri mempunyai tingkat underpriced rendah daripada perusahaan yang baru karena mengurangi asimetri informasi. Sehingga semakin lama umur perusahaan maka harga saham yang ditawarkan akan semakin rendah sehingga menghasilkan initial return rendah.

\section{Nilai Penawaran Saham terhadap Initial Return}

Hipotesis 10 diterima,Nilai Penawaran Saham berpengaruh signifikan terhadap Initial Return. Hasil SPSS menunjukan nilai t hitung $(3,102)$ lebih besar dari t tabel $(1,672)$ signifikansi $(0,003)$ lebih kecil dari 0,05 dan nilai koefisiensi ukuran perusahaan sebesar (94E-013). Hasil penelitian ini serupa dengan hasil penelitian Triani dan Nikmah (2006) dalam penelitiannya yang menyimpulkan bahwa variabel nilai penawaran saham berpengaruh signifikan terhadap return awal. Berbeda dengan (Gabriela, 2013) yang menyimpulkan bahwa nilai penawaran saham tidak berpengaruh terhadap initial return.

\section{KESIMPULAN}

Terdapat pengaruh ukuran perusahaan, EPS, PER, reputasi underwriter, dan Nilai Penawaran Saham,terhadap/nitial Return pada perusahaan yang melakukan IPO, sedangkan financial leverage, ROA, proporsi kepemilikan pemegang saham lama, reputasi auditor, dan umur perusahaan tidak berpengaruh signifikan terhadap Initial Return pada perusahaan yang melakukan IPO.

\section{Saran}

Pertama, meningkatkan kinerja perusahan sehingga mampu menambah asset perusahaan karena terbukti bahwa asset perusahaan dapat meningkatkan initial return.Kedua, meningkatkan pendapatan bersih perusahaan sehingga laba perusahaan juga akan meningkat, jika laba perusahaan meningkat, earning per share juga akan meningkat. Karena terbukti bahwa earning per share dapat meningkatkan initial return.Ketiga, meningkatkan kinerja perusahaan, sehingga nilai price earning ratio semakin kecil.semakin kecil nilai price 
earning ratio semakin baik kinerja perusahaan kinerja per lembar saham juga akan mempengaruhi banyaknya investor yang membeli saham dan menerima initial return yang maksimal. Keempat, memilih underwriter dengan reputasi baik karena underwriter berkualitas akan memberikan keyakinan lebih bagi investor serta mengurangi tingkat resiko perusahaan sehingga dapat memberikan initial return bagi investor. Dan terakhir, menawarkan saham dengan harga yang tinggi, karena semakin besar nilai saham yang ditawarkan initial return yang didapat akan semakin tinggi dan ketidakpastian dimasa yang akan datang semakin kecil.

\section{Keterbatasan Penelitian}

Keterbatasan penelitian ini terletak dalam hal masih adanya hasil uji statistik deskriptif yang menunjukkan nilai mean lebih kecil dari nilai standar deviasi dimana masih banyak data yang buruk dalam penelitian ini. Variabel yang memiliki nilai mean lebih kecil daripada nilai standar deviasi adalah variabel ukuran perusahaan, earning per share, return on asset, reputasi auditor, nilai penawaran saham dan initial return.

\section{Agenda Penelitian Yang Akan Datang}

Untuk penelitian selanjutnya dapat menggunakan metode lain seperti metode analisis regresi logistic dan menambahkan variabel faktor-faktor lain yang diduga mempengaruhi Initial Return pada perusahaan yang melakukan IPO seperti tingkat inflasi, tingkat suku bunga, dan kondisi ekonomi serta mengklasifikasikan data karena nilai standar deviasi dalam penelitian ini masih banyak yang melebihi nilai mean. 


\section{DAFTAR PUSTAKA}

Akuntan Online, Achmad Deni Daruri, 2012, "Transparasi Emiten Dinilai

Lemah", diunduh dari (http://akuntanonline.com/showdetail.php?mod=art\&id=175\&t=Transpransi\%20

Emiten\%20Dinilai\%20Lemah\&kat=Ekonomi, pada tanggal 17 Desember 2012.

Estiyanti, Ni Made dan Yasa G. W. , 2012, "Pengaruh FaktorKeuanganDanNonKeuangan PadaPeringkat ObligasiDiBursaEfek Indonesia", Simposium Nasional Akuntansi XV.

Gabriela, Like S., "Analisa Faktor-Faktor Yang Mempengaruhi Initial Return Setelah Initial Public Offering (IPO)", Jurnal Vol. 1, No.2, 67-72

Ghozali, Imam, 2011, "Aplikasi Analisis Multivariate Dengan Program IBM SPSS 19", Edisi 5, Badan Penerbit Universitas Diponegoro

Haryani, Maria A.K., dan Muchamad S., 2012, "PengaruhCorporate GovernanceTerhadapKetepatan Waktu Corporate Internet ReportingPadaPerusahaan YangTerdaftarDi Bursa EfekIndonesia", Simposium Nasional Akuntansi XV.

Indriantoro, Nur dan Bambang Supomo.2002."Metodologi Penelitian".Jakarta: Indeks.

Junaeni, Irawati dan Rendi Agustian, 2013, "Analisis Faktor-Faktor Yang Mempegaruhi Tingkat Underpricing Saham Pada Perusahaan Yang Melakukan Initial Public Offering di BEI", ISSN, Vol.1, No.1, Mei-Juni

Kompas, Asih K.W, Anastasia L.Y., Teddy G.,Yuwono T.,2012, "Kisruh Bakrie”, diunduh dari (http://

bisniskeuangan.kompas.com/read/2012/10/03/13523048/Bakrie.Samin.Tan.dan.Rothschild), pada tanggal 03 Oktober 2012 pukul 13.52.

Mukhlis, M. Zainul , 2012, "Pengaruh Underpricing Pada Penawaran Saham Perdana Di Bursa Efek Indonesia Tahun 2008-2010", Jurnal Ekonomi “Ekonomi Muda Kreatif", Vol.1, No.1

Purwanto, Agus, 2012, "Pengaruh Manajemen Laba,AsymmetryInformation Dan Pengungkapan Sukarela Terhadap Biaya Modal', Simposium Nasional Akuntansi XV.

Ratnasari dan Hudiwinarsih, 2013, "Analisis Pengaruh Informasi Keuangan, Non Keuangan serta Ekonomi Makro Terhadap Underpricing Pada Perusahaan Ketika IPO", Jurnal Buletin Studi Ekonomi, Vol.18, No.2, Agustus

Sasongko, Noer, Rina Trisnawati dan Wiyadi, 2012, "Pengukuran Manajemen Laba: PendekatanTerintegrasi", Simposium Nasional Akuntansi XV.

Sulistio, Helen, 2005, "Pengaruh Informasi Akuntansi dan Non Akuntansi Terhadap Initial Return: Studi Pada Perusahaan yang Melakukan Initial Public Offering Di Bursa Efek Jakarta", Simposium Nasional Akuntansi VIII, 87-99.

Triani, Apriliani dan Nikmah, 2006, "Reputasi Penjamin Emisi, Reputasi Auditor, Persentase Penjamin Emisi, Ukuran Perusahaan dan Fenomena Underpricing: Studi Empiris Pada Bursa Efek Jakarta", Simposium Nasional Akuntansi IX, Agustus

Widiyanti, Novi W. dan Ferdyan Dwi Kusuma, 2013, "Analisis Informasi Akuntansi dan Non Akuntansi Terhadap Initial Return Saham pada Perusahaan yang Melakukan IPO Di Bursa Efek Indonesia", Simposium Nasional Akuntansi XVI, 568-600.

http://www.idx.co.id 


\section{LAMPIRAN}

Tabel 1

\section{Hasil Uji Statistik Deskriptif}

\begin{tabular}{|l|r|r|r|r|r|}
\hline \multicolumn{7}{|c|}{ Descriptive Statistics } \\
\hline SIZE & N & \multicolumn{1}{|c|}{ Minimum } & \multicolumn{1}{c|}{ Maximum } & \multicolumn{1}{c|}{ Mean } & Std. Deviation \\
EPS & 58 & 22185,00 & 44992171,00 & 4444208,90 & 8425440,98723 \\
PER & 58 & $-35,00$ & 843,00 & 90,5948 & 163,53252 \\
LEV & 58 & $-13,60$ & 961,54 & 63,1672 & 145,14397 \\
ROA & 58 &, 03 & 4,18 &, 6053 &, 53094 \\
PPS & 58 & $-5,20$ & 40,26 & 6,8640 & 8,37857 \\
AUD & 58 & 50,10 & 97,00 & 77,1884 & 11,91909 \\
UND & 58 &, 00 & 1,00 &, 3793 &, 48945 \\
AGE & 58 &, 00 & 1,00 &, 5345 &, 50317 \\
NPS & 58 & 1,00 & 75,00 & 17,7069 & 15,27297 \\
IR & 58 & 82000000000 & 33236437800000 & $3,886 E+012$ & 5742817630830,7 \\
Valid N (listwise) & 58 & $-31,50$ & 72,73 & 19,6895 & 23,83442 \\
\hline
\end{tabular}

Sumber : Data Sekunder diolah, 2014

Tabel 2

Hasil Pengujian Normalitas dengan Uji Kolmogorov-Smirnov

\begin{tabular}{|ll|r|}
\hline \multicolumn{2}{|c|}{ One-Sample Kolmogorov-Smirnov Test } \\
\hline N & & $\begin{array}{c}\text { Unstandardiz } \\
\text { ed Residual }\end{array}$ \\
Normal Parametersa,b & Mean & 58 \\
& Std. Deviation &, 0000000 \\
Most Extreme & Absolute & 11,85429185 \\
Differences & Positive &, 113 \\
Kolmogorov-Smirnov Z & Negative &, 089 \\
Asymp. Sig. (2-tailed) & &,- 113 \\
\hline
\end{tabular}

a. Test distribution is Normal.

b. Calculated from data.

Tabel 3

\section{Hasil Uji Multikolinieritas}

\begin{tabular}{|c|c|c|c|c|c|c|c|c|}
\hline \multicolumn{9}{|c|}{ Coefficients $^{a}$} \\
\hline \multirow{2}{*}{\multicolumn{2}{|c|}{ Model }} & \multicolumn{2}{|c|}{$\begin{array}{c}\text { Unstandardized } \\
\text { Coefficients }\end{array}$} & \multirow{2}{*}{$\begin{array}{c}\begin{array}{c}\text { Standardized } \\
\text { Coefficients }\end{array} \\
\text { Beta }\end{array}$} & \multirow[b]{2}{*}{$\mathrm{t}$} & \multirow[b]{2}{*}{ Sig. } & \multicolumn{2}{|c|}{ Collinearity Statistics } \\
\hline & & $\mathrm{B}$ & Std. Error & & & & Tolerance & VIF \\
\hline \multirow[t]{11}{*}{1} & (Constant) & $\begin{array}{ll}-4,887 \\
\end{array}$ & 6,334 & &,- 772 & ,444 & & \\
\hline & SIZE & ,603 & ,257 & ,232 & 2,348 & ,023 & ,725 & 1,379 \\
\hline & EPS & ,052 & 015 &, 309 & 3,399 &, 001 & ,853 & 1,172 \\
\hline & PER & , 101 & 036 & 276 & 2,759 & 008 & ,704 & 1,420 \\
\hline & LEV & $-1,897$ & 2,688 &,- 065 &,- 706 & ,484 & ,845 & 1,183 \\
\hline & ROA & 126 & ,172 &, 069 & ,730 & ,469 & ,793 & 1,261 \\
\hline & PPS &, 005 & ,068 &, 007 &, 075 & ,941 & ,825 & 1,212 \\
\hline & AUD & 2,872 & 4,071 & ,070 & ,706 & ,484 & ,710 & 1,408 \\
\hline & UND & 11,469 & 3,774 & 281 & 3,039 &, 004 & ,829 & 1,206 \\
\hline & AGE & 026 & ,115 &, 020 & ,226 & ,822 & ,891 & 1,123 \\
\hline & NPS & $1,94 \mathrm{E}-013$ &, 000 & ,278 & 3,102 &, 003 & ,877 & 1,141 \\
\hline
\end{tabular}

Sumber : Data Sekunder diolah, 2014

DAMPAK INFORMASI AKUNTANSI DAN NON AKUNTANSI TERHADAP INITIAL RETURN SAHAM PADA PERUSAHAAN YANG MELAKUKAN INITIAL PUBLIC OFFERING DI BURSA EFEK INDONESIA 
Tabel 4

Hasil Uji Heteroskedastisitas dengan Uji Glejser

\begin{tabular}{|c|c|c|c|c|c|c|}
\hline \multicolumn{7}{|c|}{ Coefficients $^{a}$} \\
\hline & & \multicolumn{2}{|c|}{$\begin{array}{c}\text { Unstandardized } \\
\text { Coefficients }\end{array}$} & \multirow{2}{*}{$\begin{array}{c}\text { Standardized } \\
\text { Coefficients } \\
\text { Beta }\end{array}$} & \multirow[b]{2}{*}{$\mathrm{t}$} & \multirow[b]{2}{*}{ Sig. } \\
\hline \multicolumn{2}{|c|}{ Model } & $\mathrm{B}$ & Std. Error & & & \\
\hline 1 & (Constant) & 21,532 & 11,301 & & 1,905 &, 063 \\
\hline & SIZE & ,204 & ,458 & ,069 & ,446 & ,658 \\
\hline & EPS & ,010 &, 027 &, 053 & ,366 & ,716 \\
\hline & PER & ,056 & ,065 &, 137 & ,866 & ,391 \\
\hline & LEV & $-6,165$ & 4,796 &,- 185 & $-1,285$ & ,205 \\
\hline & ROA &,- 525 & ,307 &,- 255 & $-1,709$ & ,094 \\
\hline & PPS & ,215 &, 122 & ,258 & 1,766 & ,084 \\
\hline & AUD & $-9,836$ & 7,262 &,- 213 & $-1,354$ & , 182 \\
\hline & UND & $-1,187$ & 6,733 &,- 026 &,- 176 & ,861 \\
\hline & AGE &,- 110 & ,205 &,- 075 &,- 536 &, 595 \\
\hline & NPS & $-1,5 E-013$ &, 000 &,- 188 & $-1,331$ & , 190 \\
\hline
\end{tabular}

a. Dependent Variable: ABS_RES

Sumber : Data Sekunder diolah, 2014

Model Summary'

\begin{tabular}{|l|r|r|r|r|r|}
\hline Model & $\mathrm{R}$ & $\mathrm{R}$ Square & $\begin{array}{c}\text { Adjusted } \\
\text { R Square }\end{array}$ & $\begin{array}{c}\text { Std. Error of } \\
\text { the Estimate }\end{array}$ & $\begin{array}{c}\text { Durbin- } \\
\text { Watson }\end{array}$ \\
\hline 1 &, $817^{\mathrm{a}}$ &, 668 &, 597 & 13,05462 & 1,700 \\
\hline
\end{tabular}

a. Predictors: (Constant), NPS, AGE, ROA, EPS, UND, LEV, AUD, PPS, SIZE, PER

b. Dependent Variable: IR

Sumber : Data Sekunder diolah, 2014

Tabel 6

Hasil Uji Parsial (Uji t)

\begin{tabular}{|c|c|c|c|c|c|c|c|c|}
\hline \multicolumn{9}{|c|}{ Coefficients $^{a}$} \\
\hline \multirow[b]{2}{*}{ Mod } & & \multicolumn{2}{|c|}{$\begin{array}{c}\text { Unstandardized } \\
\text { Coefficients }\end{array}$} & \multirow{2}{*}{$\begin{array}{c}\begin{array}{c}\text { Standardized } \\
\text { Coefficients }\end{array} \\
\text { Beta }\end{array}$} & \multirow[b]{2}{*}{$\mathrm{t}$} & \multirow[b]{2}{*}{ Sig. } & \multicolumn{2}{|c|}{ Collinearity Statistics } \\
\hline & & B & Std. Error & & & & Tolerance & VIF \\
\hline \multirow[t]{11}{*}{1} & (Constant) & $-4,887$ & 6,334 & &,- 772 & ,444 & & \\
\hline & SIZE & ,603 & ,257 & ,232 & 2,348 & ,023 & ,725 & 1,379 \\
\hline & EPS & ,052 & ,015 & ,309 & 3,399 & ,001 & ,853 & 1,172 \\
\hline & PER & 101 & ,036 & ,276 & 2,759 & ,008 & ,704 & 1,420 \\
\hline & LEV & $-1,897$ & 2,688 &,- 065 &,- 706 & ,484 & ,845 & 1,183 \\
\hline & ROA & , 126 & ,172 & ,069 & ,730 & ,469 & ,793 & 1,261 \\
\hline & PPS &, 005 & ,068 & ,007 & , 075 & ,941 & ,825 & 1,212 \\
\hline & AUD & 2,872 & 4,071 & ,070 & ,706 & ,484 & ,710 & 1,408 \\
\hline & UND & 11,469 & 3,774 & ,281 & 3,039 & ,004 & ,829 & 1,206 \\
\hline & AGE & ,026 & , 115 & ,020 & ,226 & ,822 & ,891 & 1,123 \\
\hline & NPS & 1,94E-013 & ,000 & ,278 & 3,102 & ,003 & 877 & 1,141 \\
\hline
\end{tabular}

Sumber : Data Sekunder diolah, 2014 
Tabel 7

\section{Hasil Uji Simultan (Uji F)}

\begin{tabular}{|c|c|c|c|c|c|c|}
\hline \multicolumn{7}{|c|}{ ANOVA } \\
\hline Model & & $\begin{array}{l}\text { Sum of } \\
\text { Squares }\end{array}$ & $d f$ & Mean Square & $\mathrm{F}$ & Sig. \\
\hline 1 & $\begin{array}{l}\text { Regression } \\
\text { Residual } \\
\text { Total }\end{array}$ & $\begin{array}{r}16114,165 \\
8009,881 \\
24124,046\end{array}$ & $\begin{array}{l}10 \\
47 \\
57\end{array}$ & $\begin{array}{r}1611,416 \\
170,423\end{array}$ & 9,455 &, $000^{a}$ \\
\hline
\end{tabular}

a. Predictors: (Constant), NPS, AGE, ROA, EPS, UND, LEV, AUD, PPS, SIZE, PER

b. Dependent Variable: IR

Sumber : Data Sekunder diolah, 2014

\begin{tabular}{|l|r|r|r|r|r|}
\multicolumn{7}{|c|}{ Model Summary $^{\text {' }}$} \\
\hline Model & R & R Square & $\begin{array}{c}\text { Adjusted } \\
\text { R Square }\end{array}$ & $\begin{array}{c}\text { Std. Error of } \\
\text { the Estimate }\end{array}$ & $\begin{array}{c}\text { Durbin- } \\
\text { Watson }\end{array}$ \\
\hline 1 &, $817^{\text {a }}$ &, 668 &, 597 & 13,05462 & 1,700 \\
\hline
\end{tabular}

a. Predictors: (Constant), NPS, AGE, ROA, EPS, UND, LEV, AUD, PPS, SIZE, PER

b. Dependent Variable: IR

Sumber : Data Sekunder diolah, 2014

KERANGKA PEMIKIRAN TEORITIS

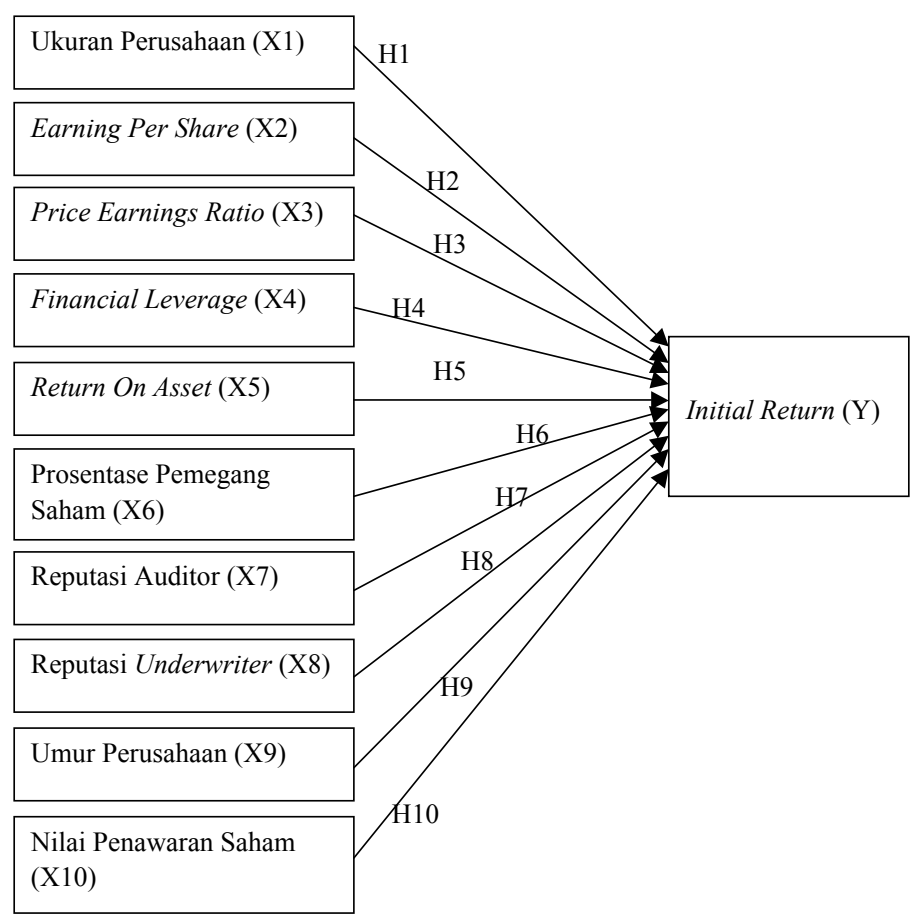

DAMPAK INFORMASI AKUNTANSI DAN NON AKUNTANSI TERHADAP INITIAL RETURN SAHAM PADA PERUSAHAAN YANG MELAKUKAN INITIAL PUBLIC OFFERING DI BURSA EFEK INDONESIA 
JURNAL AKUNTANSI INDONESIA

\begin{tabular}{|c|c|c|c|c|c|c|c|c|c|c|c|c|c|c|}
\hline \multicolumn{15}{|c|}{ RESEARCH GAP } \\
\hline \multirow[t]{2}{*}{ NO } & \multirow{2}{*}{$\begin{array}{c}\text { Nama } \\
\text { Peneliti } \\
\text { (tahun) }\end{array}$} & \multicolumn{13}{|c|}{ Variabel } \\
\hline & & Size & EPS & PER & LEV & ROA & PPS & AUD & UND & AGE & NPS & DSR & IE & EC \\
\hline \multirow[t]{2}{*}{1} & $\begin{array}{c}\text { Triani dan } \\
\text { Nikmah }\end{array}$ & $\mathrm{S}$ & & & & & & TS & TS & $\mathrm{S}$ & $\mathrm{S}$ & $\mathrm{S}$ & $\mathrm{S}$ & $\mathrm{S}$ \\
\hline & Nikmah (2006) & & & & & & & & & & & & & \\
\hline \multirow[t]{2}{*}{2} & Widiyanti dan & S & $\mathrm{S}$ & TS & $S$ & $S$ & S & TS & TS & TS & & & & \\
\hline & Kusuma (2013) & & & & & & & & & & & & & \\
\hline 3 & Gabriela (2013) & $S$ & & & & & & $\mathrm{~S}$ & TS & TS & TS & & & \\
\hline
\end{tabular}

keterangan: SIZE (ukuran perusahaan)

EPS (Earning Per Share)

PER (Price Earning Ratio)

LEV (tingkat Leverage)

ROA (Return On Asset)

PPS (Proporsi Kepemilikan

Pemegang Saham Lama)

AUD (Reputasi Auditor)

UND (Reputasi Underwriter)

NPS (Nilai Penawaran Saham)

DSR (Deviasi Standar Return)

IE (Jenis Perusahaan)

EC (kondisi Ekonomi)

S berpengaruh signifikan

TS tidak berpengaruh signifikan 